\title{
盲導犬は自動車をどのように認識しているか
}

\author{
福井良太 \\ 財団法人栃木盲導犬センター
}

\section{How guide dogs recognize moving cars}

\author{
Fukui Ryota
}

Tochigi Guide Dog Center

\begin{abstract}
抄 録
盲導犬の候補犬を訓練する際、走行する自動車やオートバイなどに対する反応（歩行の停止）を向上させ るために「交通訓練」（トラフィック・トレーニング）と呼ばれる訓練を行うのが一般的であるが、効果的 な交通訓練の方法、頻度及び難易度については一致した意見がない。そこでこの研究では、盲導犬および盲 導犬の候補犬が自動車に対してどのような印象を持ち、何を基準に反応しているのかについて調べる実験を 行った。結果的には、交通訓練を行っていない犬にとって、車は「乗る対象」であり、動く車に対しても危 険意識はゼロに近い事が観察された。また、交通訓練を行った犬であっても、左右および後方から接近する 車に対して確実に反応できるのは、車が約 1 メートル以内に接近した時のみであった。さらに、犬が前方 に強く集中すると、後方から近づく車に対する反応がいっそう遅れる傾向が見られた。これらの所見から、 より安全な盲導犬歩行を実現する為に、車との反応距離に関する基準、訓練前から車への危険意識を育てる 事の必要性、さらに盲導犬歩行時の技術的な諸点についても言及した。
\end{abstract}

キーワード：盲導犬、交通事故、自動車、認識、反応距離

\section{Summary}

In Guide Dog training, it is a common practice to perform "Traffic Training" in which guide dog candidates learn to stop immediately when approaching traffic is recognized. However, there are no certain guidelines as to how many traffic training sessions are necessary and how it should be done. In this paper, the main discussion point is as follows; how Guide Dogs learn to recognize and respond to moving cars. In the results, it is observed that untrained dogs have little aversion to moving cars, because most of them have had happy experiences going out in cars with puppy raisers. Also, traffic-trained dogs could respond to moving cars only when the cars approached to within a distance of 1 meter, especially if the traffic was coming from the right, left, or from behind; this result was more obvious (responses were slower) when dogs concentrated on the tasks in front of them, such as curbs and obstacles. From these observations, this paper refers to the following: 1 . Guidelines on the distance a guide dog is expected to keep between the dog and car, 2. The possibility of introducing traffic training during puppy scheme, and 3. Important technical advice to visually impaired persons when walking with a guide dog.

Keywords : guide dog, traffic accident, car/vehicle, recognition, critical distance 


\section{序 論}

盲導犬の候補犬を訓練する際、走行中の自動車やオート バイなどに対する反応を向上させるために「交通訓練」 （トラフィック・トレーニング）と呼ばれる訓練を行うの が一般的である。自動車などに対する理想的な反応とは、 歩行中であれば停止すること、信号待ちなどで停止中であ れば動かないこと（静止）である。※注 1

盲導犬の候補となる犬達（候補犬）は、生後約 2 ヶ月 でパピーウォーカーと呼ばれる飼育ボランティアの家庭に 預けられ、人間社会の生活に馴染ませる（社会化・パピー プログラムと呼ばれる)。その間、自動車での移動に慣れ ることも重要な要素の 1 つであり、犬達はほとんど例外な く車での移動に慣れるが、交通訓練を行う事はない。1歳 になると訓練センターに戻り本格的な訓練を始めるが、交 通訓練を始めるのは、訓練開始から $2 \sim 3$ ヶ月経って、十 字路・段差・障害物などの基本的な作業が理解できるよう になった頃である。訓練所によっては、6〜8ヶ月経過し ないと交通訓練を始めないところもある。交通訓練のスケ ジュールは訓練所によって差異が見られるが、連続して行 わず、 1 週間、1 1 月と間隔をあけて、徐々に難易度を上 げて行う事が多いようである。

交通訓練の具体的な方法としては、信号を横断中、ある いは横断しようとする候補犬に対して、職員が運転する車 を色々な角度から接近させる。最初は物理的に動けないよ うな距離にまで接近させ、同時に圧迫感を与えてネガティ ブな印象を与える。次に、徐々に犬と車との距離を離して ゆき、犬が自らの判断で停止・静止する反応を引き出して ゆく。犬によってまちまちだが、4～ 5 回の訓練で概ね良 好な反応が得られる事が多い。

このように、交通訓練の目的は、候補犬に対して「動く 車は危険なもの」、「車が近づいてきたら停止する」という 意識をつけることである。車が近づいてきた際、犬が危険 と感じる距離 (犬と車の距離) のことを「クリティカル. ディスタンス」と呼ぶが、適切なクリティカル・ディスタ ンスを学習させる事が最大のポイントであることは言うま でもない。しかしながら、適切なクリティカル・ディスタ ンスとは何メートルかと問われると、一致した意見を見出 す事は難しい。例えば、クリティカル・ディスタンスを $5 \mathrm{~m}$ に設定して訓練すると、車と人の距離が近い都心部で は、横断歩道を渡ることは困難になる。さらに、現状で は、効果的な交通訓練の方法、頻度及び難易度に関しても 根拠となる要素がそしい。

そこで、この研究では、自動車に対する犬の学習、日本
の道路事情、交通訓練の頻度・難易度などを考慮に入れ、 行動実験を交えながら、盲導犬の候補犬（以下、候補犬） が自動車に対してどのような印象を持ち、何を基準に反応 しているのかを調べる実験を行った。実験後、考察に基づ き、現実的な基準設定と、より安全な盲導犬歩行を実現す る為に推奨されるプログラムやテクニックを提示した。

※注 1 : 念のために申し添えておくと、盲導犬は、使用者 が自動車に衝突する前に停止する事はできても、衝突しそ うな状況から使用者を救うことはできない。できないという のは、訓練するのが不可能という意味である。盲導犬には、 停止あるいは静止をすることで事故を未然に防ぐという機 能のみを期待するというのが、この研究の前提である。

\section{研究方法}

I 。実験 1 ：交通訓練を受けた事がない候補犬が、ゆる やかに接近する車に対して、どのくらいの距離でどの ような反応を見せるのか観察した。歩行訓練を 3 〜 ケ月受けた候補犬 7 頭に対して、約 $5 \mathrm{~m}$ 離れた位置か ら車を 5 ～ $6 \mathrm{~km} / \mathrm{h}$ で徐々に接近させた。接近中は 5 〜 6km/h を保ち、犬から $1 \mathrm{~m}$ 手前のマーカーでいつ たん減速し、そこからさらに犬の真横のマーカー（ゼ ロメートル）まで進んで停止する。候補犬が車以外の 刺激に対して反応するのを制限し、かつ車への反応を 自由に行えるようにするため、犬を訓練士の左側に、 「待て」の命令をかけずに座らせた。実験中、訓練士 は横に立っているだけである。車は犬の左側面から接 近する。対象の 7 頭はいずれもラブラドール・レトリ バーであり、盲導犬としての資質を持ち、1歳齢から 訓練を開始している。実験時は、基本的な作業はこな せるが、交通訓練を受けた事はない。なお、今回の実 験に関わった訓練犬はすべてラブラドール・レトリバ 一である。実験に使用した車はトヨタのハイブリッド カー「プリウス」で、実験時はモーターのみで駆動さ せたため、エンジン音や排気ガスは出ていない。候補 犬の中には、エンジン音や排気ガスに反応する犬もい るためである。(図 1 ～3)

II. 実験 2 : 交通訓練を 5 回以上行った候補犬が、左右を 横切る自動車に対してどのように反応するか観察し た。歩行訓練を $6 \sim 8$ ヶ月受けた候補犬 4 頭に、見通 しの良い、片側 2 車線ずつの大通りに打いて、道路横 断の命令をかけた。ただし横断する場所は横断歩道で はなく、車が $60 \mathrm{~km} / \mathrm{h}$ 以上のスピードで間断なく通 過する。訓練士は、走行する車がそれぞれ $50 \mathrm{~m} 、 10 \mathrm{~m}$ 、 
$1 \mathrm{~m}$ の距離に近づいた時に発進の命令を出した。犬が 誤って発進した場合は、危険がないように停止させた。

III. 実験 3 ：玩具とフードを使用して、犬を正面方向に 集中させた状態で、後方から物体を低速で通過させ、 犬がどの時点で反応するかを観察した。前方に集中す る事によって、後方から迫る物体に対する反応が遅れ るかどうかを調べるもので、一般に言われる「視野が

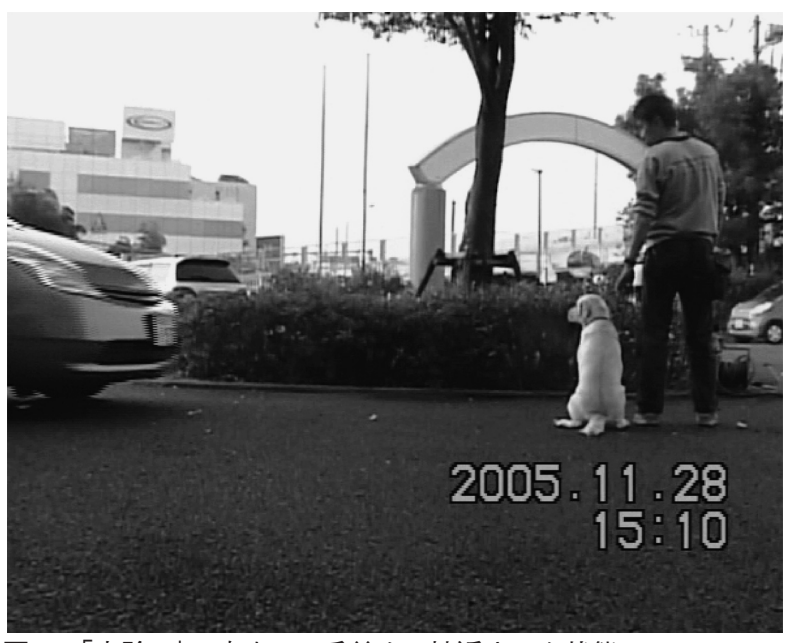

図 1 「実験 $1 」$ で車を $2 m$ 手前まで接近させた状態

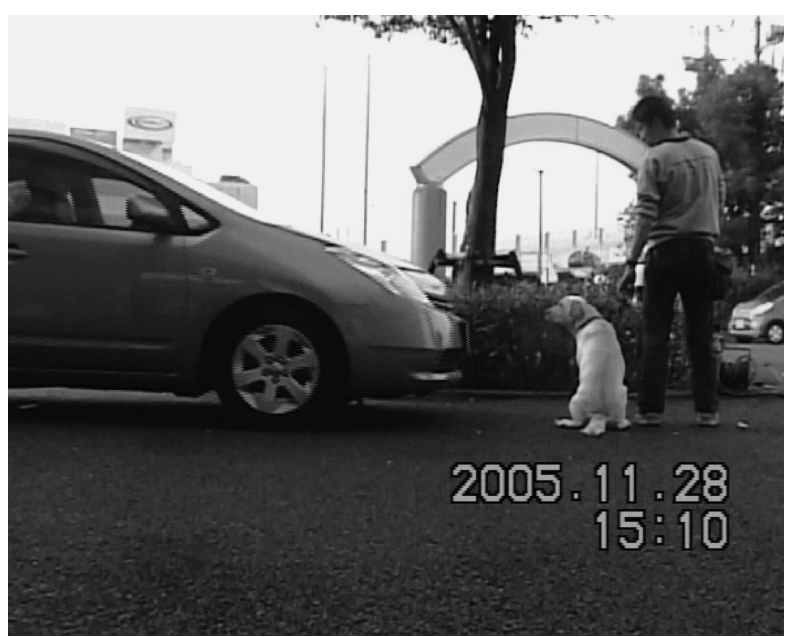

図 2 「実験 $1 」$ で車を $0.5 \mathrm{~m}$ 手前まで接近させた状態

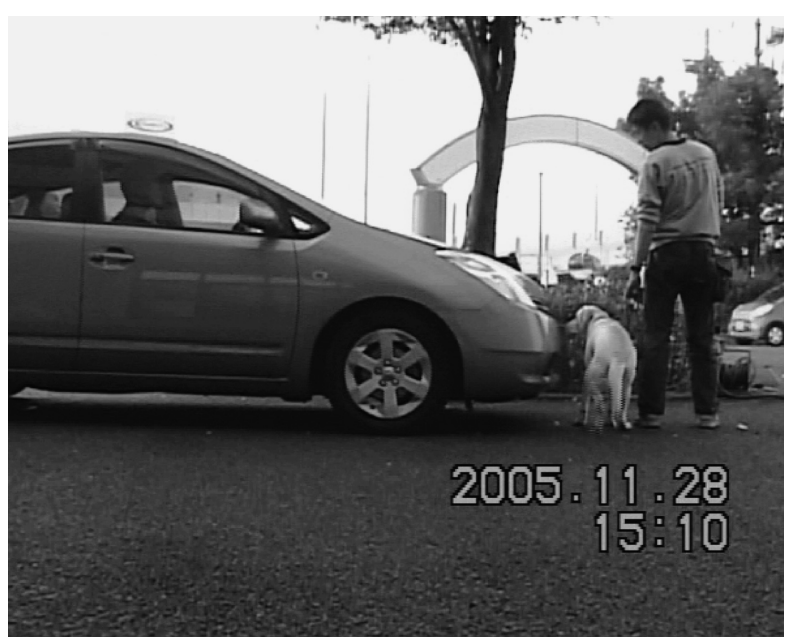

図3「実験1」で車を $0 m$ まで接近させた状態（無反応）
狭くなる」という現象が起こるかどうかを検証した。 実際の盲導犬歩行では、前方の段差に集中した場合 に、後方からの巻き込みの車に対して反応が遅れる、 という可能性がある。玩具とフードの 2 種類の刺激を 使用したのは、ラブラドールの特性としてフードへの 執着が非常に強いため、フードにより強く集中した場 合、後方からの物体への反応が、玩具の場合よりも遅 れることが予想されたからである。具体的な方法とし ては、訓練センターの廊下に犬を座らせ、 $5 \mathrm{~m}$ 先に玩 具を提示する。犬が玩具に集中した時点で、犬の顔の 横約 $10 \mathrm{~cm}$ の距離で、縦・横・奥行きそれぞれ $50 \mathrm{~cm}$ のダンボール箱を後方から静かに通過させる。左右か らビデオを撮り、犬が反応した時点の視野角を算出す る。玩具で実験を行った 3 日後に、正面の刺激を玩 具からフードにかえて行い、2つの刺激間で反応の違 いを観察した。なおこの実験は、合計 10 頭の候補犬 を対象に行った。内訳は、交通訓練を 5 回以上受け たことのある、訓練期間 $6 \sim 8$ ケ月の犬が 4 頭、交通 訓練を受けた事のない、訓練期間 $3 \sim 4$ ヶ月の犬が 6 頭である。(図4～7)

\section{研究結果}

I. 実験 $1: 7$ 頭の平均反応距離は $30 \mathrm{~cm}$ であった。接近 する車に対して近づく行動をした犬（ポジティブに反 応した犬）、遠ざかる行動をした犬（ネガティブに反

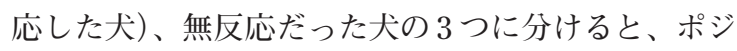
ティブ 3 頭、ネガティブ 3 頭、無反応 1 頭となる。反 応別に見てみると、ポジティブ反応の平均は $36 \mathrm{~cm} 、$ ネガティブ反応の平均は $33 \mathrm{~cm}$ 、無反応は $0 \mathrm{~cm}$ であ る。最も早く反応したケースは、ポジティブ反応が $100 \mathrm{~cm}$ 、ネガティブ反応が $70 \mathrm{~cm}$ であり、 $1 \mathrm{~m}$ ルより 手前から反応した犬は皆無であった。つまり、交通訓 練を行っていない段階でのクリティカル・ディスタン スは、平均 $30 \mathrm{~cm}$ であると言える。

II. 実験 2 : 走行する車との距離が $1 \mathrm{~m} 、 10 \mathrm{~m} 、 50 \mathrm{~m}$ いず れの場合も、「発進の命令をかけられても発進しない」 のが候補犬として求められる行動である。時速 $60 \mathrm{~km} / \mathrm{h}$ の車が $50 \mathrm{~m}$ 走るのに 3 秒しかかからないため、 距離が $50 \mathrm{~m}$ あっても発進するべきではない。しかし、正 解率が $100 \%$ だったのは、車が $1 \mathrm{~m} の$ 距離に接近した 時のみであった。 $10 \mathrm{~m}$ の距離では約 $50 \%$ に落ち、さ

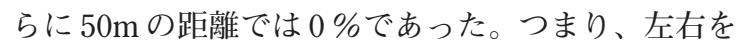
高速で横切る自動車に対しての反応 (歩行の停止) が 確実と言えるのは、犬が物理的に停止せざるを得ないほ 
どの距離 $(1 \mathrm{~m}$ 以内) に車が近づいた時のみであった。

III. 実験 3 : 犬の正面を 0 度とした場合、反応角度は玩具 の場合が 124 度、フードの場合は 117 度と、フードの 方が若干反応は遅れるものの、大差なかった。犬の平 均的な視野角は片側 120 度と言われているので (1) フードの場合は平均よりもやや遅れていると言える。 玩具での実験後にフードを用いて実験したため、犬が 学習した結果、反応があまりかわらなくなった可能性 もある。注目すべきは、正面の刺激の種類に関わら ず、犬が正面に強く集中するような素振り（顔を傾け るなど）をした時、反応が遅れる傾向が見られた（最 も遅い犬は 90 度近くであった)。また、ダンボール箱 が犬の耳のそばを通過する時、まず耳が動いてから、 目で確認しようとする犬が半数近くいた。耳に感じる 風圧によって反応したとも考えられるが、もしそうで あれば、後方からの巻き込みの車を、犬は聴覚を補助 的に利用して知覚しているのかもしれない。最後に、 交通訓練の経験の有無と訓練期間は、反応の速さには 関係がなかった。

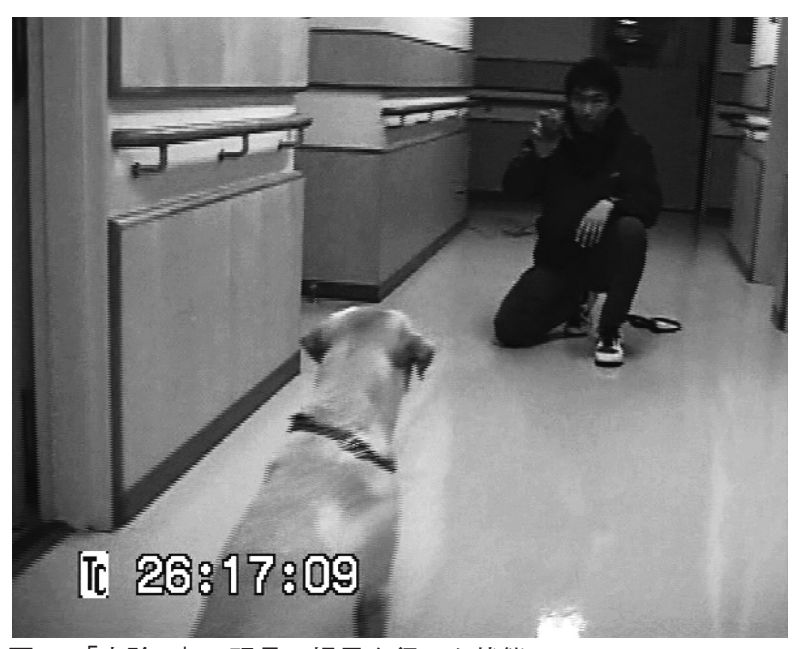

図 4 「実験 3」で玩具の提示を行った状態

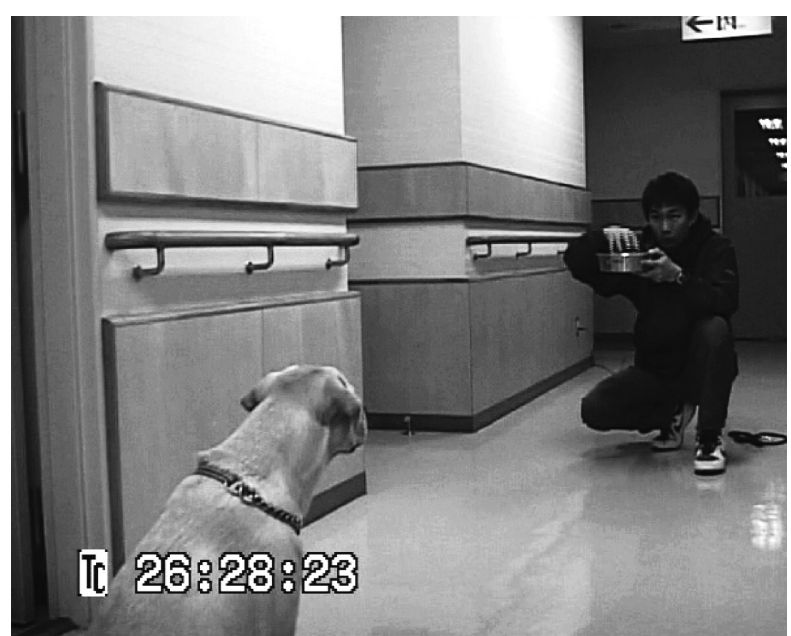

図 5 「実験 3」でフードの提示を行った状態

\section{考察}

I . 実験 1 の結果から、犬はパピープログラム期と訓練期 を通して、「1m まで接近する車は危険ではない」と 学習し、条件付けされると考えられる。これは、「車 は乗るもの・車は外出のサイン」という学習に加え て、日本の特殊な道路事情（車との距離が近い、歩車 道の区別のない道路が多い等）によって、かなり近く まで接近する車に対しても危険意識を持たないように 感覚が鈍化したとも推測できる。このことを検証する 為には、道路幅が広く、歩道の整備がなされている欧 米やオーストラリアでパピーウォーカーに預けられた 候補犬で、同じ実験を行う必要がある。

II 。また、実験 2 の結果から、特に高速で走行する車に対 しては、盲導犬の判断の確実性は高くないと言える。 唯一確実と言えるのは、車との距離が $1 \mathrm{~m}$ の場合のみ であるが、これは「判断」というよりも、物理的に動 く事ができなかったという意味で「反応」と呼ぶほう

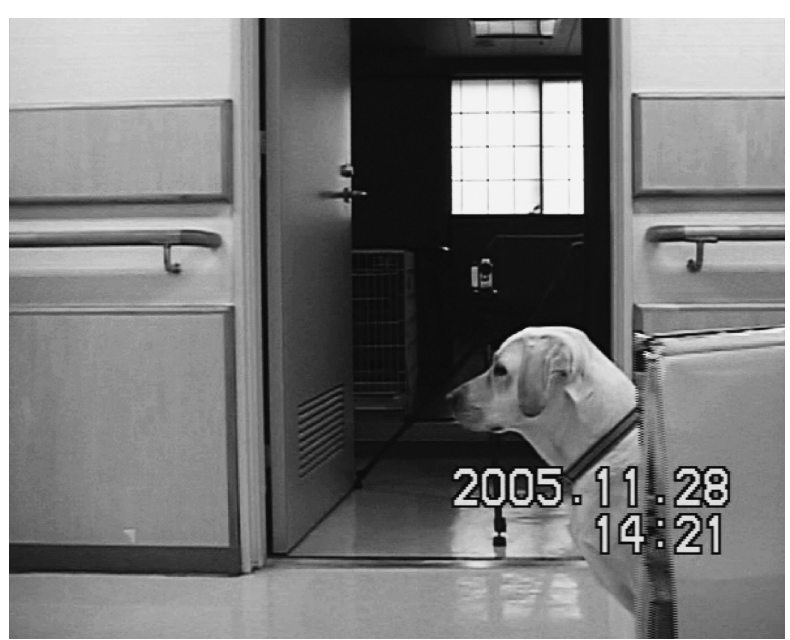

図6「実験 3」において、犬を前方に集中させ、後方から箱を通 過させる (反応前)

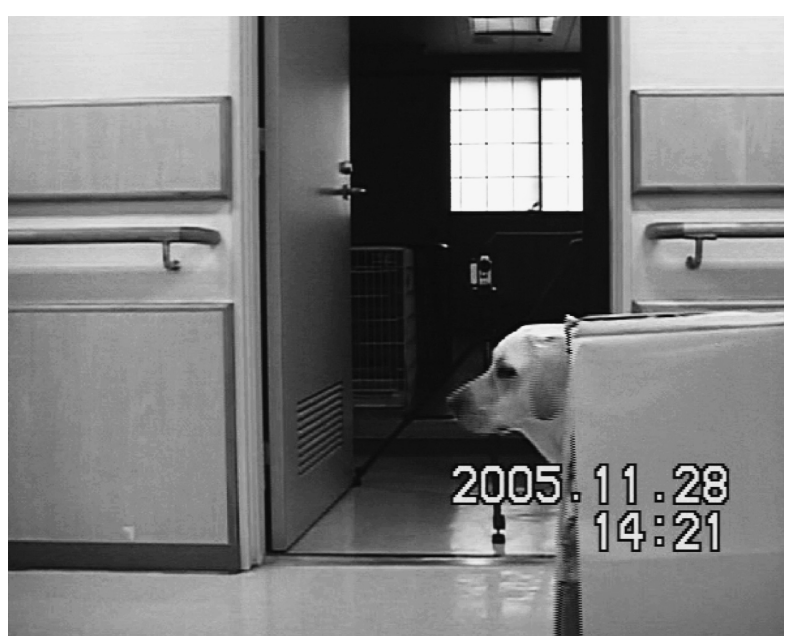

図 7 「実験 3」において、犬が箱に反応した瞬間 
がふさわしい。このことをさらに検証する為には、同 じ実験を低速走行する車で行う必要があり、今後の課 題である。ここで、一般の歩行者が横断歩道を渡る場 合、危険な車（衝突の可能性があるもの）とそうでな い車をどのような基準によって判断しているのかを考 えてみると、車の速度・減速の度合い・車との距離・ 道路の形状・見通しの良さ・天気・道幅・ドライバー の視線や表情などが挙げられる。この中で、盲導犬に 判断（あるいは反応）をさせる事ができるのは、車と の距離のみであると思われる。他の要素を含めて訓練 することは、犬の処理能力を大きく超えているし、た とえある程度の訓練が可能だとしても、確実性は極め て低いと思われる。

III. 最後に、実験 3 の中で、犬が正面方向に強く集中し た場合、最も反応の遅い犬では約 90 度、つまり真横 に物体が来て初めて気付くというケースも観察され た。さらに集中の度合いが増すと、反応がいっそう遅 れる可能性がある。盲導犬は進行方向の維持、進行方 向の横断位置の発見など、正面方向に集中する場合が ほとんどであるから、自動車の後方からの卷き込み、 左右からの危険な横切りに対しては、特に反応が遅れ る事が予想される。ただし、このことが即、重大な事 故につながるとは限らない。なぜなら、盲導犬との歩 行中、使用者は聴覚等を使って周囲の状況を確認し、 あるいは通行人に援助依頼をして、盲導犬と安全性を 補完しあうことが多いからである。

\section{結論}

今回の研究だけでは、盲導犬の自動車に対する認識、と いう大きなテーマに関しての結論を出す事は困難である。 しかし、今回の実験結果から、走行する車の認識と危険回 避に関する限り、犬の能力には限界があると言えることは 確かである。盲導犬育成に関わる訓練士や指導員、そして 盲導犬使用者は、このことを体験的に知っていると思われ るが、今回の実験はそれを実証するものである。前述した ように、盲導犬歩行は使用者の判断、盲導犬の判断、そし て周囲のサポートがあって初めて成り立つものであり、盲導 犬が万能で、すべての情報を処理しているのではないこと を改めて強調しておきたい。最後に、前述した 3 つ実験・ 観察結果を踏まえて、以下の 3 点を提案して結びとしたい。

I . 盲導犬が保つべきクリティカル・ディスタンスの基準 を $1 \mathrm{~m}$ とする。

走行する自動車と歩行者の距離が狭い、歩車道の区別 のない道路が多い、という日本の道路事情を鑑み、さ
らに犬の状況判断能力を考慮に入れると、自動車に対 する盲導犬のクリティカル・ディスタンスの基準を $1 \mathrm{~m}$ とすることが適当であると思われる。

II . パピープログラム中から、1 $\mathrm{m}$ のクリティカル・ディ スタンスを意識付ける。パピープログラム中の犬の大 半は、車を「乗る対象」「外出のサイン」としてポジ ティブな印象を持っており、中には車に飛びついて乗 ろうとする犬も少なくない。パピープログラム中から 徐々にクリティカル・ディスタンスの意識付けができ れば、短期間で集中的に行う交通訓練よりも高い効率 性と確実性が期待できる。具体的にはまず、自家用車 に飛びつくという習慣を改め、車の手前 $1 \mathrm{~m}$ で犬を座 らせ、「待て」をかけたうえで車のドアを開け、犬を 乗車させるといった、一連の動きを徹底してもらうこ とから始めるべきであろう。次に、走行中の車は危険 であるという意識をつけるために、クラクションなど の音を立てながら低速走行する車を横切らせる。感受 性豊かな仔犬であるから、車自体に恐怖心を植え付け ないよう、成犬以上に注意する必要がある。

III. 盲導犬使用者は、ドライバーに対する意思表示はしっ かりと、盲導犬に対する命令語は控えめに行う。

天候や角度によって、ドライバーからは、盲導犬の存 在が分かりにくい事が意外に多い。例えば、盲導犬の 右側に使用者が立っている場合（左手持ちの場合）、 使用者の右側あるいは右後方から接近する車からは、 盲導犬は認識しゔらい。そのような場合ドライバー は、視覚障害者が横断しようとしているとは思わない ため、衝突のリスクが高まる可能性がある。このた め、使用者は白杖や指符（進行方向への指差し）を効 果的に使う事によって、ドライバーに横断の意思を明 確に伝える必要がある。また、使用者が盲導犬に対し て道路横断開始の命令を出す場合、そのほとんどが正 面方向への発進の命令である事を考えると、命令は強 い口調のものよりも、促すような指示のほうが望まし い。これは、実験 3 で明らかになったように、犬を正 面方向に強く集中させてしまうと、犬の視野を正面に 限定する事になり、結果として左右・後方から迫る車 への意識が薄れてしまうからである。また、促すよう な指示を与える事で、犬に自主的な判断の余地を与え る効果も期待できる。

\section{参考文献}

1. OFRI,R (1999). Optics \& Visual Physiology in Veterinary Ophthalmology, 3rd edition (Chapter 4, pp. 183-216. ). Edited by K.N. Gelatt Lippincott Williams \& Wilkins, Philadelphia. 